\title{
Growth and Feed Utilization of Boer x Kacang Crossbred Goats Offered Total Mixed Rations of Different Protein and Energy Levels
}

\author{
Ginting SP, Simanihuruk K, Antonius, Tarigan A \\ Indonesian Goat Research Station, P.O. Box 1 Galang, Sumatera Utara \\ E-mail: simonginting04@gmail.com \\ (received 10-10-2017; revised 21-11-2017; accepted 18-12-2017)
}

\begin{abstract}
ABSTRAK
Ginting SP, Simanihuruk K, Antonius, Tarigan A. 2017. Pertumbuhan dan pemanfaatan pakan kambing persilangan Boer x Kacang yang diberi pakan komplit dengan kandungan protein dan energi berbeda. JITV 22(4): 188-195. DOI: http://dx.doi.org/10.14334/jitv.v22i4.1782

Penelitian bertujuan untuk mengevaluasi pertumbuhan dan pemanfaatan pakan pada kambing persilangan Boer $\mathrm{x}$ Kacang yang diberi pakan komplit dengan taraf protein dan energi berbeda. Empat kombinasi pakan komplit yang mengandung 16 atau $18 \%$ protein kasar dan 2650 atau $2850 \mathrm{Kkal} \mathrm{ME} / \mathrm{kg}$ BK digunakan dalam penelitian acak lengkap dengan pola faktorial. Sebanyak 28 ekor kambing persilangan Boer x Kacang $(14,5 \pm 1,14 \mathrm{~kg})$ dan umur antara 4-5 bulan secara acak dialokasikan kepada salah satu dari keempat perlakuan pakan komplit (7 ekor ternak/TMR). Pengaruh perlakuan pakan dianalisis dengan analisis sidik ragam model linier dan apabila terdapat pengaruh perlakuan selanjutnya di uji dengan uji Duncan's Multiple Range. Terjadi peningkatan konsumsi BK $(\mathrm{P}<0,05)$ jika kandungan energy metabolism pakan meningkat dari 2650 menjadi 2850 $\mathrm{Kkal} / \mathrm{kg} \mathrm{BK}$, namun konsumsi BK tidak dipengaruhi $(\mathrm{P}>0,05)$ oleh taraf protein kasar dalam pakan. PBBH tidak meningkat $(\mathrm{P}>0,05)$ dengan peningkatan kandungan protein kasar dan energy metabolism dalam pakan. Disimpulkan bahwa dengan konsumsi pakan komplit pada kambing persilangan Boer x Kacang yang tergolong tinggi, maka kandungan protein kasar $16 \%$ dan densitas energy metabolism $2850 \mathrm{Kkal} / \mathrm{kg}$ BK dapat menghasilkan PBBH yang tinggi.
\end{abstract}

Kata Kunci: Kambing, Pakan Komplit, Taraf Protein, Taraf Energi

\section{ABSTRACT}

Ginting SP, Simanihuruk K, Antonius, Tarigan A. 2017. Growth and feed utilization of Boer x Kacang crossbred goats offered total mixed rations of different protein and energy levels. JITV 22(4): 188-195. DOI: http://dx.doi.org/10.14334/jitv.v22i4.1782

The aim of this study was to evaluate the growth of and feed utilization by Boer $\mathrm{x}$ Kacang crosses goats fed on total mixed ration differing in protein and energy levels. Four total mixed rations combination were formulated to contain 16 and $18 \%$ crude protein and 2650 and $2850 \mathrm{Kcal} \mathrm{ME} / \mathrm{kg}$ DM (dried matter) energy density. Twenty-eight male Boer x Kacang crosses goats $(14.5 \pm 1.14 \mathrm{~kg})$ and of age ranging from 4 to 5 months were randomly allocated to one of these four TMRs (total mixed rations) (7 animals/TMR). The effects of dietary treatment were assessed using the general linear model and significance of the diet effects was detected using Duncan's multiple range test. Dry matter intake increased as metabolizable energy density of diet increased from 2650 to $2850 \mathrm{Kcal} / \mathrm{kg} \mathrm{DM}$, but it is not affected by increasing crude protein level from 16 to $18 \%$. The average daily gains were not improved $(\mathrm{P}>0.05)$ as the crude protein levels and metabolizable energy density of diet increased. Crude protein levels and ME density did not affect $(\mathrm{P}>0.05)$ the $\mathrm{DM}, \mathrm{OM}$ and energy digestibility, but NDF digestibility was affected by the ME density of diets $(\mathrm{P}<0.05)$. Daily $\mathrm{N}$ intakes were greater $(\mathrm{P}<0.0 \%)$ in goats received diets higher in the crude protein and metabolizable energy levels. At this high rate of feed intake this type of goats are able to gain optimally when offered feed with crude protein level of $16 \%$ and metabolizable energy density of $2850 \mathrm{Kcal} / \mathrm{kg} \mathrm{DM}$.

Key Words: Goats, Total Mixed Ration, Protein Level, Energy Level

\section{INTRODUCTION}

Crossbreeding schemes between introduced Boer goats and indigenous Kacang Goats have been undertaken at the Goat Research Institute at Sungai Putih, North Sumatera. The production performances evaluation of the Boer $x$ Kacang crossbreds are currently in progress, and the ultimate goal of this program is to create a $50 \%$ Boer and $50 \%$ Kacang genotype with superior performance potentials compared to that of native Kacang goats, particularly in the trait of growth rate and body weight. It is generally accepted that crossbred genotypes would only express their performances to their genetic potentials when raised under optimum production system (Bryant et al. 2005), in which nutrition plays a critical element. Improving the nutrition status of ruminants through increasing the intake of main nutrients such as crude 
protein and metabolizable energy resulted in increased dry matter intake and digestibility, $\mathrm{N}$ retention and liveweight gain (Rios-Rincon et al. 2014; Singh et al. 2013). However, the magnitude of the responses vary greatly across breeds (Negesse et al. 2001; Hwangbo et al. 2009). This is indicative of different protein and energy requirements for maintenance and production of various genotype of goats under different production system.

In Indonesia, the integration of ruminant animals including goats with palm oil plantation is being promoted as one of the prospective production systems. The availability and efficient utilization of various types of feeds to support animal production under this production system play a vital role. The aim of this study was to evaluate the growth and feed utilization of Boer $x$ Kacang crossbreds offered diets differing in the crude protein and metabolizable energy levels in the form of totally mixed ration and using palm oil fronds as the sole roughage.

\section{MATERIALS AND METHODS}

\section{Diets, animals and experimental design}

Four total mixed rations (TMR) using palm oil fronds as the sole roughage were formulated to have different crude protein levels (16\% and 18\%) and metabolizable energy levels $(2650 \mathrm{Kcal} / \mathrm{kg} \mathrm{DM}$ and $2850 \mathrm{Kcal} / \mathrm{kg} \mathrm{DM})$. Ingredients and the calculated chemical compositions (DM basis) of the four TMRs are presented in Table 1. Oil palm fronds were obtained from the oil palm plantations. After removing the leaves, the stems were ground using shredder and mixed thoroughly with other ingredients. Twenty-eight male Boer $x$ Kacang crossed goats of similar body weight $(14.5 \pm 1.14 \mathrm{~kg})$ and age (4 to 5 months old) were randomly allocated to one of the four dietary treatments each replicated seven times with one goat per replicate. Animals were put in individual metabolic cage equipped with troughs and water container. Feeds were offered ad libitum by allowing refusal at approximately $10 \%$. The animals were fed twice daily at 08:00 and 14:00 each of equal amounts. Water was available at all the times. Animals were adapted to their pens and dietary treatments for 14 days and the feeding trial lasted for 90 days. During the feeding trial feeds offered and refusals were recorded daily while animal's body weights were measured biweekly. Following the feeding trial a digestion trial was performed during which offered feed and individual refusals, feces and urine were collected and sampled daily for five consecutive days. Faecal samples (10\%) were collected and pooled by animal. Parts of the faecal samples were processed for $\mathrm{DM}$ determination $\left(80^{\circ} \mathrm{C}\right.$ for $\left.48 \mathrm{~h}\right)$. Other parts were dried at $600^{\circ} \mathrm{C}$, ground to pass through $1 \mathrm{~mm}$ screen and stored in refrigerator for laboratory analyses. Urine from individual animal was collected in plastic container containing $100 \mathrm{ml}$ of $10 \%$ sulphuric acid to maintain $\mathrm{pH}$ below 3.0 and keep in a freezer until analysed. Blood was sampled at the end of the digestion trial from the jugular vein just before morning meal. Blood samples were stored at $-20^{\circ} \mathrm{C}$ before analyses.

\section{Laboratory analyses}

Feeds, individual refusals, faeces were analyzed for dry matter (DM), organic matter (OM) and nitrogen according to the standard procedures (AOAC 2012) and for neutral detergent fiber (NDF) and acid detergent fiber (ADF) using the procedures described by Van Soest et al. (1991). Urine was analyzed for nitrogen. Blood samples were analyzed for glucose and urea-N using Vitalab Flexor auto analyzer kits.

\section{Statistical analyses}

The experiment was arranged in a completely randomized design with a $2 \times 2$ factorial arrangement. Each treatment consisted of seven replicates. The effects of dietary treatments on daily gains, intake, digestibility, nitrogen balances, blood metabolites were 
Table 1. Ingredient and chemical compositions of the experimental diets

\begin{tabular}{|c|c|c|c|c|}
\hline \multirow{2}{*}{$\begin{array}{l}\mathrm{ME}(\mathrm{Kcal} / \mathrm{kg}) \\
\mathrm{CP}(\%)\end{array}$} & \multicolumn{2}{|c|}{$2650 \mathrm{Kcal} / \mathrm{kg} \mathrm{DM}$} & \multicolumn{2}{|c|}{$2850 \mathrm{Kcal} / \mathrm{kg} \mathrm{DM}$} \\
\hline & $16 \% \mathrm{CP}$ & $18 \% \mathrm{CP}$ & $16 \% \mathrm{CP}$ & $18 \% \mathrm{CP}$ \\
\hline \multicolumn{5}{|l|}{ Ingredients $(\%)$} \\
\hline Indigofera leaf meal & 20.0 & 20.0 & 20.0 & 20.0 \\
\hline Palm kernel cake & 29.0 & 19.0 & 10.0 & 8.0 \\
\hline Molasses & 5.0 & 5.0 & 5.0 & 5.0 \\
\hline Soybean meal & 14.0 & 24.0 & 18.0 & 27.0 \\
\hline Bone meal & 1.0 & 1.0 & 1.0 & 1.0 \\
\hline Mineral premix & 1.0 & 1.0 & 1.0 & 1.0 \\
\hline Corn & 0 & 0 & 19.0 & 10.0 \\
\hline Palm oil fronds & 30.0 & 30.0 & 30.0 & 30.0 \\
\hline \multicolumn{5}{|c|}{ Chemical compositions } \\
\hline $\mathrm{CP}, \%$ & 15.95 & 17.97 & 15.81 & 18.10 \\
\hline $\mathrm{Ca}, \%^{\mathrm{a}}$ & 0.53 & 0.59 & 0.55 & 0.62 \\
\hline $\mathrm{P}, \%^{\mathrm{b}}$ & 0.32 & 0.31 & 0.30 & 0.33 \\
\hline NDF, $\%$ & 43.57 & 46.46 & 45.12 & 44.71 \\
\hline $\mathrm{ADF}, \%$ & 31.33 & 32.81 & 32.39 & 31.53 \\
\hline DE (Kkal/kg DM) & 2680 & 2660 & 2872 & 2865 \\
\hline
\end{tabular}

${ }^{\mathrm{a}, \mathrm{b}}$ Calculated

assessed statistically using analysis of variance and a general linear model (GLM) procedure in SAS (1989). The statistical model used is Yijk $=\mu+\square \mathbf{i}+\beta \mathbf{j}+\square \beta \mathrm{ij}$ + cijk where Yijk is the individual observations, $\mu$ is the overall mean, $\square \mathrm{i}(\mathrm{i}=1,2)$ is the energy levels, $\beta \mathrm{j}(\mathrm{j}=1,2)$ is the protein levels and $\square \beta \mathrm{ij}$ is the energy-protein interactions and eijk is the unexplained variation assumed normally and independently distributed. The significance of the diet effects was determined at $\mathrm{P} \leq 0.05$. The treatment means were compared using the Duncan's multiple range test.

\section{RESULTS AND DISCUSSION}

\section{Feed intake and daily gains}

The effects of dietary treatments on the feed intake and growth performances are shown in Table 2. There was no interaction between energy and protein levels on feed intake. The DM intake was affected by energy level but not by the protein levels of the diets. Similar trend was seen when DMI was expressed as percentage of body weight. Goats fed on high energy level had higher DM intake. The level of DM intake in all dietary treatments was considerably high, ranging from 5.1 to $5.7 \%$ BW. These levels of dry matter intake are comparable to the observation of Limea et al. (2009) in Carribran goats that reached level of feed intakes of 5.1 to $5.4 \% \mathrm{BW}$. This high feed intake level in the present experiment could be associated with the type of diets offered as totally mixed ration in which all feed ingredients have been ground. Thus, the physical fill effect of the diet which could be a limiting factor of feed intake in ruminant animals may have been minimal in the present experiment. As goat kids fed on the higher energy diet the feed intake was higher as well. This might indicate that the high energy level used in this study may have not reached the dietary energy density that will limited DM intake. Rios-Rincon et al. (2014) found that the DM intake was limit when the level of metabolizable energy of diet is $3050 \mathrm{Kcal} / \mathrm{kg}$. At lower metabolizable energy diets (ranging from 2380 to $2720 \mathrm{Kcal} / \mathrm{kg}$ ), Wang et al. (2015), however, did not detect the effect of dietary energy level on feed intake in Hanian black goats. The absence of crude protein level effects on feed intake observed in this study is in agreement with Wang et al. (2015) that offered goats with diets CP levels of 15 and $17 \%$ or with Rios-Rincon et al. (2014) offered lambs with diets of 14.5 and $17.5 \%$ CP contents. Some studies (Ebrahimi et al. 2007; Kioumarsi et al. 2008; Wang et al. 2015) indicated that the effects of crude protein levels of diets on feed intake to be more significant when the protein levels were set below 14\%, although Boonsaen et al. (2017) did not find the effect of protein levels on feed intake in steers fed diets with CP level of 12 and $14 \%$. 
Table 2. Dry matter intake and daily gains of Boer x Kacang crossbred kids offered total mixed ration with difference in energy and protein levels

\begin{tabular}{|c|c|c|c|c|c|c|c|c|}
\hline \multirow{3}{*}{ Item } & \multicolumn{4}{|c|}{ Energy level (Kcal ME/kg) } & \multicolumn{4}{|c|}{ Main effect } \\
\hline & \multicolumn{2}{|c|}{2650} & \multicolumn{2}{|c|}{2850} & \multicolumn{2}{|c|}{$\begin{array}{c}\text { Energ level } \\
\text { (Kcal ME/kg) }\end{array}$} & \multicolumn{2}{|c|}{ Protein level ( \%) } \\
\hline & $\begin{array}{c}16 \% \\
\mathrm{CP}\end{array}$ & $\begin{array}{c}18 \% \\
\mathrm{CP}\end{array}$ & $\begin{array}{c}16 \% \\
\mathrm{CP}\end{array}$ & $\begin{array}{c}18 \% \\
\mathrm{CP}\end{array}$ & 2650 & 2850 & 16 & 18 \\
\hline DMI, g/d & $957.8 \pm 46.27^{\mathrm{a}}$ & $1006.5 \pm 35.16^{\mathrm{a}}$ & $1113.3 \pm 43.78^{\mathrm{b}}$ & $1125.6 \pm 38.92^{\mathrm{b}}$ & $982.15^{\mathrm{a}}$ & $1119.45^{\mathrm{b}}$ & 1035.55 & 1059.90 \\
\hline DMI, g/kg BW & $51.15 \pm 4.75^{\mathrm{a}}$ & $52.2 \pm 3.67^{\mathrm{a}}$ & $56.54 \pm 4.59^{b}$ & $57.11 \pm 3.44^{\mathrm{b}}$ & $51.68^{\mathrm{a}}$ & $56.83^{b}$ & 53.85 & 54.66 \\
\hline Initial BW, kg & $14.5 \pm 0.93$ & $13.9 \pm 0.97$ & $15.31 \pm 1.41$ & $14.97 \pm 1.58$ & 14.2 & 15.14 & 14.91 & 14.44 \\
\hline Final BW, kg & $22.95 \pm 0.71$ & $23.73 \pm 1.15$ & $25.57 \pm 0.43$ & $24.44 \pm 1.69$ & 23.34 & 25.01 & 24.26 & 24.09 \\
\hline $\mathrm{ADG}, \mathrm{g}$ & $97.21 \pm 6.17$ & $106.24 \pm 5.15$ & $112.15 \pm 4.96$ & $108.87 \pm 7.88$ & 101.73 & 110.51 & 104.68 & 107.56 \\
\hline
\end{tabular}

a,b Different superscripts in the same column significantly difference $(\mathrm{P}<0.05)$; ns: non significantly difference

Table 3. Apparent digestibility coefficients (\%) of nutrients in goats kids fed diet containing varying energy and protein levels

\begin{tabular}{|c|c|c|c|c|c|c|c|c|}
\hline \multirow{3}{*}{ Item } & \multicolumn{4}{|c|}{ Energy level (Kcal ME/kg) } & \multicolumn{4}{|c|}{ Main effect } \\
\hline & \multicolumn{2}{|c|}{2650} & \multicolumn{2}{|c|}{2850} & \multicolumn{2}{|c|}{$\begin{array}{c}\text { Energ level } \\
\text { (Kcal ME/kg) }\end{array}$} & \multicolumn{2}{|c|}{ Protein level (\%) } \\
\hline & $\begin{array}{c}16 \% \\
\mathrm{CP}\end{array}$ & $\begin{array}{c}18 \% \\
\mathrm{CP}\end{array}$ & $\begin{array}{c}16 \% \\
\mathrm{CP}\end{array}$ & $\begin{array}{c}18 \% \\
\mathrm{CP}\end{array}$ & 2650 & 2850 & 16 & 18 \\
\hline Dry Matter & $71.98 \pm 4.96$ & $68.44 \pm 3.83$ & $70.11 \pm 4.33$ & $67.60 \pm 3.98$ & 70.21 & 68.86 & 71.05 & 68.02 \\
\hline Organic Matter & $75.50 \pm 3.52$ & $71.14 \pm 4.89$ & $73.43 \pm 2.31$ & $69.51 \pm 4.26$ & 72.82 & 71.47 & 73.96 & 70.33 \\
\hline $\mathrm{NDF}$ & $59.81 \pm 4.58^{\mathrm{a}}$ & $57.56 \pm 5.85^{\mathrm{a}}$ & $53.05 \pm 3.98^{\mathrm{b}}$ & $54.26 \pm 2.39 b^{b}$ & $58.69^{\mathrm{a}}$ & $53.66^{\mathrm{b}}$ & 56.43 & 55.91 \\
\hline Energy & $76.23 \pm 2.9$ & $74.35 \pm 4.72$ & $75.99 \pm 5.21$ & $71.75 \pm 3.89$ & 75.29 & 73.87 & 76.11 & 73.05 \\
\hline
\end{tabular}

a,b Different superscripts in the same column significantly difference $(\mathrm{P}<0.05)$; ns: non significantly difference 
Protein and energy level of diets did not significantly $(\mathrm{P}>0.05)$ affect average daily gains and final weights of the goats kids. As expected, increasing in feed intake resulted in increased crude protein and metabolizable energy intake. The calculated daily crude protein intake of goats in the low and high protein diets were 166 and 191g, respectively, while the metabolizable energy intake was calculated to be 2623 and $3108 \mathrm{Kcal} /$ day in low and high energy diets, respectively. These figures are greater than those recommended by Mandal (2005) as daily crude protein requirement $(84 \mathrm{~g})$ and metabolizable requirement (1800 $\mathrm{Kcal} / \mathrm{d}$ ) for growth of the Indian local goats. The crude protein and metabolizable energy requirement of Boer $\mathrm{x}$ Kacang crossbred goats used in this study might be higher than those of Indian goats, but the level of CP protein and the metabolizable energy intake in all dietary treatments may have been sufficient to fulfill the requirement for their optimal growth as indicated by the relatively high growth rate of goats in all dietary treatments. A greater growth rate was reported by Ryan et al. (2007) in Boer crossbred goat $(125 \mathrm{~g} / \mathrm{d})$ and by Mahgoub et al. (2005) in Omani goats $(133 \mathrm{~g} / \mathrm{d})$ when the animals were fed on high-concentrate diets.

Apparent nutrient and energy digestibility of dietary treatments are shown in Table 3. The results indicated that there was no significant effect $(\mathrm{P}>0.05)$ of different metabolizable energy and crude protein levels on the apparent DM and OM and energy digestibility except the NDF digestibility, and no protein and energy level interaction was discovered. The apparent digestion coefficient of DM, OM and energy in all dietary treatments were considered to be high, which might be related to the relatively great proportion of highly digested ingredients used in the diets. Also, the physical process of diet in which each ingredient was ground to form the total mixed ration might have contributed to this relatively high digestibility coefficient of the nutrients. These results are comparable to the findings of Robinson et al. (2006) or Elamin et al. (2012) working on Nubian and dessert goats. Karimizadeh et al. (2017) discovered that processing feed into complete feed block or mash can improve the DM digestibility. The NDF digestibility was greater $(\mathrm{P}<0.05)$ in goat kids offered diet with lower energy density. This might be related to the significantly lower intake level of goat fed diet with low energy density. Although feed retention time was not measured in this study, lower feed intake may resulte in longer retention time of the feed in the reticulo rumen which allowed the animal to better digest the feeds.

The $\mathrm{N}$ balance by goat kids under varying dietary energy and protein levels is presented in Table 4. There was no interaction $(\mathrm{P}>0.05)$ between energy levels and protein levels on the $\mathrm{N}$ balance. The daily average $\mathrm{N}$ intake by goat kids was significantly affected $(\mathrm{P}<0.05)$ by the energy and crude protein levels of the diet. Goats received diets with higher energy and protein levels consumed greater $\mathrm{N}$ compared to those fed diets of lower energy and protein levels. The fecal $\mathrm{N}$ output was not influenced by dietary energy and protein levels $(\mathrm{P}>0.05)$, although numerically, there was a trend that fecal $\mathrm{N}$ output was greater in goats when fed diets with higher protein and energy levels. A positive association between $\mathrm{N}$ intake and fecal $\mathrm{N}$ output has been observed by several authors (Pattanaik et al. 2003; Yang et al. 2014). Urinary $\mathrm{N}$ output was influenced $(\mathrm{P}<0.05)$ by the dietary protein levels, but not by dietary energy levels. The greater urinary $\mathrm{N}$ output found in goat offered diet with higher protein levels in the present study was in accordance with results reported by several authors (Lohakare et al. 2006; Cantalapiedra-Hijar 2009). A possible increase in the endogenous $\mathrm{N}$ losses due to increased feed intake in the higher protein level group could relate to the increasing urinary $\mathrm{N}$ output. The $\mathrm{N}$ retention $(\mathrm{g} / \mathrm{d})$ and $\mathrm{N}$ absorbed (as percentage of $\mathrm{N}$ retention) were affected $(\mathrm{P}<0.05)$ by the dietary protein level, but not by dietary energy levels. $\mathrm{N}$ retention is considered as the most common indicator of the protein nutrition status of ruminants. In the present study, positive $\mathrm{N}$ retention was observed in all dietary treatments and it is well accepted that $\mathrm{N}$ retention depends on the intake of nitrogen and the amount of fermentable carbohydrate of the diet. The greater $\mathrm{N}$ retention in the high protein level compared to the low protein level found in the present study might be associated the higher feed intake level. The similar $\mathrm{N}$ retention (as percentage of $\mathrm{N}$ intake) may be an indicative of the adequacy of metabolizable energy intake at the high or low protein level.

Blood metabolites are presented in Table 5. There was no interaction of energy $x$ protein. Concentration of urea $\mathrm{N}$ was not affected by the dietary energy level but it was greater $\mathrm{P}<0.05$ ) in goats offered diet with higher protein level. The source of plasma urea-N was reported to be from the NH3 liver conversion of excess amino acids and from ruminal degradation of dietary crude protein (Huntington et al. 2001). Thus, the higher BUN in the high dietary protein goats in present study should be from the greater crude protein intake that resulted in more amino acids transferred to the liver and more crude protein has been degraded in the rumen. The greater urinary $\mathrm{N}$ excretion in goats fed dietary with high protein level (Table 4) may be indicative of more protein has been degraded in the rumen, since there is a linear increase in urinary $\mathrm{N}$ with increasing protein degradation in the rumen (Javaid et al. 2008; Kalscheur et al. 2006). Plasma glucose concentration was higher $(\mathrm{P}<0.05)$ in goats fed high energy level, but it was not affected the dietary protein levels. 
Table 4. Nitrogen balance of goat kids fed diets with different energy and protein levels

\begin{tabular}{|c|c|c|c|c|c|c|c|c|}
\hline \multirow{3}{*}{ Item } & \multicolumn{4}{|c|}{ Energy level (Kcal ME/kg) } & \multicolumn{4}{|c|}{ Main effect } \\
\hline & \multicolumn{2}{|c|}{2650} & \multicolumn{2}{|c|}{2850} & \multicolumn{2}{|c|}{ Energ level (Kcal ME/kg) } & \multicolumn{2}{|c|}{ Protein level (\%) } \\
\hline & $16 \%$ & $18 \%$ & $16 \%$ & $18 \%$ & 2650 & 2850 & 16 & 18 \\
\hline $\mathrm{N}$ intake $(\mathrm{g} / \mathrm{d})$ & $23,44 \pm 1.02$ & $26.94 \pm 1.26$ & $28.16 \pm 1.64$ & $32.59 \pm 1.37$ & $25.19^{\mathrm{a}}$ & $30.38^{b}$ & $25.80^{\mathrm{a}}$ & $29.77^{\mathrm{b}}$ \\
\hline Fecal N (g/h) & $8.35 \pm 0.343$ & $8.84 \pm 0.22$ & $9.58 \pm 0.39$ & $10.56 \pm 0.42$ & 8.60 & 10.07 & 8.97 & 9.70 \\
\hline Urine $N(g / d)$ & $4.66 \pm 0.33$ & $6.96 \pm 0.41$ & $5.02 \pm 0.30$ & $6.50 \pm 0.37$ & 5.81 & 5.76 & $4.84^{\mathrm{a}}$ & $7.73^{\mathrm{b}}$ \\
\hline $\mathrm{N}$ absorbed (g/d) & $18.78 \pm 0.74$ & $19.98 \pm 0.66$ & $23.14 \pm 0.53$ & $25.49 \pm 0.34$ & 19.38 & 24.32 & 20.96 & 22.74 \\
\hline N Retention $(\mathrm{g} / \mathrm{d})$ & $11.43 \pm 0.05$ & $13.14 \pm 0.04$ & $11.81 \pm 0.06$ & $15.27 \pm 0.05$ & 12.29 & 13.54 & $11.62^{\mathrm{a}}$ & $14.21^{\mathrm{b}}$ \\
\hline$\%$ intake & $46.77 \pm 2.18$ & $45.40 \pm 3.05$ & $48.61 \pm 1.88$ & $47.23 \pm 2.79$ & 46.09 & 47.92 & 47.69 & 46.32 \\
\hline
\end{tabular}

Table 5. Blood metabolites in goats fed two levels of dietary energy and protein

\begin{tabular}{|c|c|c|c|c|c|c|c|c|}
\hline \multirow{3}{*}{ Item } & \multicolumn{4}{|c|}{ Energy level (Kcal ME/kg) } & \multicolumn{4}{|c|}{ Main effect } \\
\hline & \multicolumn{2}{|c|}{2650} & \multicolumn{2}{|c|}{2850} & \multicolumn{2}{|c|}{ Energ level (Kcal ME/kg) } & \multicolumn{2}{|c|}{ Protein level (\%) } \\
\hline & $16 \%$ & $18 \%$ & $16 \%$ & $18 \%$ & 2650 & 2950 & 16 & 18 \\
\hline Urea-N (mg/dl) & $24.08 \pm 1.76$ & $29.01 \pm 1.64$ & $26.33 \pm 1.72$ & $33.06 \pm 2.62$ & 26.55 & 29.70 & $25.21^{\mathrm{a}}$ & $31.04^{\mathrm{b}}$ \\
\hline Glucose (mg/dl) & $66.29 \pm 3.21$ & $68.96 \pm 2.18$ & $74.04 \pm 3.22$ & $78.32 \pm 3.68$ & $67.63^{\mathrm{a}}$ & $76.18^{b}$ & 70.17 & 73.64 \\
\hline
\end{tabular}


The plasma concentration ranged from 66 to $78 \mathrm{mg} / \mathrm{dl}$ and was comparable to those reported by Karimizadeh et al. (2017) fed goats diet with metabolizable energy concentration of $2500 \mathrm{Kcal} / \mathrm{kg} \mathrm{DM}$. This plasma glucose levels may indicative of adequate energy intake at both levels and related to the relatively high DM intake of the goats (Table 2). Sing et al. (2013) found lower plasma glucose level (47-52 $\mathrm{mg} / \mathrm{dl})$ at lower DM intake (500-600 g DM/day) compared to the DM intake in the present study. This is supported also by the insignificant effects of dietary energy levels on the blood $\mathrm{N}$ level, since energy deficiency could result in in reduced blood glucose with concomitant increase in blood urea (Yurtman et al. 2002). The insignificant effects of dietary protein level on the concentration of blood glucose observed in the present study were similar to result study of Meng et al. (2016) offered goats diet with crude protein level of $10,12.5$ and $15 \%$.

\section{CONCLUSION}

The present study shows that the Boer $\mathrm{x}$ Kacang crossbred goats have high level of DM intake when offered feeds in the form of total mixed rations. At this high rate of feed intake this type of goats are able to gain optimally when offered feed with crude protein level of $16 \%$ and metabolizable energy density of 2850 $\mathrm{Kcal} / \mathrm{kg} \mathrm{DM}$.

\section{REFERENCES}

[AOAC] Association of Official Analytical Chemist. 2012. Official methods of analyses. 19th ed. Maryland (USA): AOAC International.

Boonsaen P, Soe NW, Maittreejet W, Majarune S, Reungprim T, Sawanon S. 2017. Effects of protein and energy sources in total mixed ration on feedlot performance and carcass quality of Kamphaeng Saen steers. Agric Nat Res. 51:57-61.

Bryant M, Glina C, Carles A. 2005. Breeding strategies for sustainable improvement. In: Owen E, Kitalyi A, Jayasuriya N, Smith T, editors. Livestock and wealth creation. Nottingham (UK): Nottingham University Press. p. 215-232

Cantalapiedra-Hijar G, Yanez-Ruiz DR, Martin-Garcia AI, Molina-Alcaide E. 2009. Effects of forage:concentrate ratio and forage type on apparent digestibility, ruminal fermentation, and microbial growth in goats. J Anim Sci. 87:622-631.

Ebrahimi R, Ahmadi HR, Zamiri Mj, Rowghani E. 2007. Effect of energy and protein levels on feedlot performance and carcass characteristics of Mehfaban ram lambs. Pak J Biol Sci. 10:1679-1684.

Elamin KM, Eldar AAT, Amin AE, Abdalla FS, Hassan HE. 2012. Digestibility and nitrogen balance of Sudan goats ecotype fed different energi/protein level. Asian J Anim Sci. 6:230-239.

Javaid A, Nisa M, Sarwar M, Shahzad MA. 2008. Ruminal characteristics, blood $\mathrm{pH}$, blood urea nitrogen and nitrogen balance in Nili-ravi Buffalo (Bubalus bubalis) bulls fed diets containing various levels of ruminally degradable protein. Asian-Aust J Anim Sci. 21:51-58.

Huntington GB, Poore M, Hopkins B, Spears J. 2001. Effect of ruminal protein degradability on growth and $\mathrm{N}$ metabolism in growing beef steers. J Anim Sci. 79:533541.

Hwangbo S, Choi SH, Kim SW, Son SS, Park HS. 2009. Effects of crude protein levels in total mixed rations on growth performance and meat quality in growing Korean Black goats. Asian-Aust J Anim Sci. 22:11331139.

Kalscheur KF, Baldwin RL, Glenn BP, Kohn RA. 2006. Milk production of dairy cows fed differing concentration of rumen-degraded protein. J Dairy Sci. 89:249-259.

Karimizadeh E, Chaji M, Mohammadabadi T. 2017. Effects of physical form of diet on nutrient digestibility, rumen fermentation, rumination, growth performance and protozoa population of finishing lambs. Anim Nutr. 3:139-144.

Kioumarsi H, Khorsidi KJ, Zahedifar M, Sedavi AR, Mirhosseini SJ, Taherzadeh MR. 2008. The effect of dietary energy and protein level on performance, efficiency and carcass characteristics of Taleshi lambs. Asian J Anim Vet Adv. 3:307-313.

Liméa L, Boval M, Mandonnet N, Garcia G, Archimède H, Alexandre G. 2009. Growth performance, carcass quality, and noncarcass components if indigenous Carribean goats under varying nutritional densities. J Anim Sci. 87:3770-3781.

Lohakare JD, Pattanaik AK, Khan SA. 2006. Effect of dietary protein levels on the performance, nutrien balancea, metabolic profile and thyroid hormones of crossed calves. Asian-Aust J Anim Sci. 19:1588-1596.

Mahgoub O, Lu CD, Hameed MS, Richie A, Al-Halhali AS, Annamalai K. 2005. Performance of Omani goats fed diets containing various metabolizable energy densities. Small Rumin Res. 58:175-180

Mandal AB, Paul SS, Mandal GP, Kannan A, Pathak NN. 2005. Deriving nutrient requirements of growing Indian goats under tropical condition. Small Rumin Res. 58:201-217.

Meng F, Yuan C, Yu Z. 2016. Effects of dietary protein levels on milk production performances and serum biochemical indicators of diary goat. J Adv Dairy Res. $4: 1-5$.

Negesse T, Rodehutscord M, Pfeffer E. 2001. The effect of dietary crude protein level on intake, growth, protein retention and utilization of growing male Saanen kids. Small Rumin Res. 3:1-8. 
Pattanaik AK, Sastry VRB, Katiyar RC, Lal M. 2003. Influence of grain processing and fietary protein degradability on nitrogen metabolism, energy balance and methane production in young calves. Asian-Aust $\mathrm{J}$ Anim Sci. 16:1443-1450.

Rios-Rincón FG, Estrada-Angulo A, Plascencia A, LópezSoto MA, Castro-Pérez BI, Portillo-Loera JJ, RoblesEstrada JC, Calderón-Cortes JF, Dávila-Ramos H. 2014. Influence of protein and energy level in finishing diets for feedlot hair lambs: Growth performance, dietary energetics and carcass characteristics. Asian-Aust J Anim Sci. 27:55-61.

Robinson TF, Sponheimer M, Roeder BL, Passey B, Cerling TE, Dearing MD, Ehleringer JR. 2006. Digestibility and nitrogen retention in llamas and goats fed alfalfa, C3 grass and C4 grass hay. Small Rumin Res. 64:162-168.

Ryan SM, Unruh JA, Corrigan ME, Drouillard JS, Seyfert M. 2007. Effects of concentrate levels on carcass traits of Boer crossbred goats. Small Rumin Res. 73:67-76.

[SAS] Statistical Analysis System. 1989. SAS User's guide International Version 6. 4th ed. Cary, NC (USA): Statistical Analysis Institute Inc.
Singh VK, Pattanaik AK, Goswami TK, Sharma K. 2013. Effect of varying the energy density of protein-adequate diets on nutrien metabolism. Clinical chemistry, immune responses and grouwth of Muzaffarnagari lambs. Asian-Aust J Anim Sci. 26:1089-1101.

Van Soest PJ, Robertson JB, Lewis BA. 1991. Methods for dietary fibre, neutral detergent fibre, and nonstarch carbohydrates in relation to animal nutrition. J Dairy Sci. 74:3583-3597.

Wang D, Zhou L, Zhou H, Hou G, Shi L, Huang X, Guan S. 2015. Effects of nutritional level of concentrate-based diets on meat quality and expression levels of genes realted to meat quality in Hainan blak goats. Anim Sci J. $86: 166-173$.

Yang SY, Oh YK, Ahn HS, Kwak WS. 2014. Maintenance crude protein requirement of penned female Korean spoted deer (Cervus nippon). Asian-Aust J Anim Sci. 27:30-35

Yurtman IY, Savas T, Karaagac F, Coskuntuna L. 2002. Effects of daily protein intake levels on the oral stereotypic behaviours in energy restricted lambs. Appl Anim Behav Sci. 77:77-88. 